\title{
HOW CONTEXT SHAPES THE AUTHORITY OF INTERNATIONAL COURTS
}

\author{
KAREN J. ALTER* \\ LAURENCE R. HELFER** \\ MIKAEL RASK MADSEN***
}

I

INTRODUCTION

There is wide variation in the activity and influence of the nearly two dozen international courts (ICs) currently in existence. What factors lead some ICs to become active and prominent judicial bodies that cast a rule-of-law shadow beyond the courtroom, while others remain moribund or legally and politically sidelined? This introduction brings together experts of different ICs from the disciplines of law, political science, and sociology to collectively evaluate how institutional, political, and social contexts, and other exogenous factors influence the authority of ICs.

We are interested in when a court's formal legal authority evolves into authority in fact, or de facto authority. A key contribution of this introduction is the development of a framework to assess IC authority in fact that can be measured and assessed over time, across issue areas, in different countries, and in a disaggregated fashion. The contributors to this symposium, covering the major issue areas in which ICs operate, apply the authority metric to ten of the

Copyright $(\subseteq 2016$ by Karen J. Alter, Laurence R. Helfer \& Mikael Rask Madsen.

This article is also available at http://lcp.law.duke.edu/.

* Karen J. Alter is a Professor of Political Science and Law at Northwestern University and a Permanent Visiting Professor at iCourts: Centre of Excellence for International Courts.

** Laurence R. Helfer is Harry R. Chadwick, Sr. Professor of Law at Duke University and a Permanent Visiting Professor at iCourts: Centre of Excellence for International Courts.

*** Mikael Rask Madsen is a Professor of Law at the University of Copenhagen and Founding Director of iCourts: Centre of Excellence for International Courts. We thank iCourts and the Center for International and Comparative Law at Duke University for generous financial assistance and for hosting the two seminars where participants presented and discussed the draft papers in this issue. Research for this symposium was conducted under the auspices of iCourts, The Danish National Research Foundation's Centre of Excellence for International Courts, Grant no. DNRF105. For insightful comments on earlier drafts of this paper, we give special thanks to Allen Buchanan, Andreas Føllesdal, Ian Hurd, Bob Keohane, Geir Ulfstein, Michael Zürn, and to the participants in this special issue, an American Bar Foundation workshop, the Fourth Regional Colloquium on Globalization, International Organizations and International Law, the iCourts-PluriCourts Seminar on the Legitimacy of International Courts and Tribunals, the Caribbean Academy of Law and Court Administration 3rd Biennial Conference, and the iCourts Conference on International Jurisprudence. 
most active ICs. Our primary goal in explicating this framework is to create a metric for assessing how legal, political, and social factors shape whether an IC has any de facto authority, the scope of that authority, and whether that authority encompasses the full range of its delegated jurisdiction.

Part II analyzes the distinctive features of ICs as international institutions. We identify similarities common to all ICs and explain how ICs differ in important ways from other international institutions and from domestic courts.

Part III defines IC authority and develops a framework that permits scholars to assess differences in authority in fact, within and across courts. Building on earlier scholarship, we create a measure of authority that reflects the practices-that is, the words and actions-of different sets of actors or audiences, who range from the litigants in a specific case to a broader legal field of, for example, attorneys, government officials, and scholars. This part also explains our decision to put aside questions of actors' motives and beliefs, thus separating authority in fact from both sociological legitimacy and normative legitimacy.

This symposium focuses on how contextual factors that are largely beyond the control of international judges facilitate or hinder whether an IC has any authority in fact and, if so, the extent of that authority. Accordingly, Part IV identifies a range of institutional, social, and political factors that shape IC authority. Part IV also previews how the contributors to this symposium analyze these contextual factors as applied to different ICs. Some of our contributors also consider the ability of judges to influence these contextual factors.

Part $\mathrm{V}$ introduces a third dimension-IC power and effectiveness. We consider how far an IC's authority extends across the full range of its subject matter competence and the states subject to its jurisdiction. Some ICs establish authority that is capacious in one sense-the number of actors who accept an obligation to comply-but confined in another sense-the acceptance exists only for a narrow issue area or a few countries. So long as a court's authority is limited in this way, its political and legal shadow remains relatively small. An IC becomes more powerful and influential when its authority expands not only to a wider circle of constituencies, but also across a broader range of legal issues and countries.

Part VI concludes by summarizing the major findings of this issue and by identifying promising avenues for future research.

II

ICS AS INTERNATIONAL LEGAL INSTITUTIONS THAT FACE DISTINCT CHALLENGES

Our analysis of the authority of ICs engages with a growing literature on international authority that focuses on global governance institutions or that imports domestic concepts about institutions and legal processes into the 
international realm. ${ }^{1}$ We not only build upon this literature, but also explain how ICs possess legal authority that differs in fundamental ways from that of other international institutions and from that of domestic courts. We begin by identifying how these differences create distinctive challenges for establishing, maintaining, and building IC legal authority. ${ }^{2}$

In the most general terms, legal authority is a form of power characterized by a content-independent response to a command or order. The response is content-independent because the command is not tailored to the recipient's interests. Legal authority is more complex than parental authority, but it is similar in that subjects comply because an authoritative actor has said what conduct is required. ${ }^{3}$ Most ICs acquire formal legal authority - what many call de jure authority-through an act of delegation ${ }^{4}$ from states that establishes a court's formal right to rule on disputes falling within its jurisdiction. The legal right to rule exists even if the moral or ethical basis of that right remains contested.

Many scholars assert that ICs possess unquestioned authority simply by virtue of this act of delegation. Although delegation confers formal powers on ICs and specifies their functions in important ways, delegation alone is insufficient. A formally constituted court may receive no cases even if violations of the law under its jurisdiction are widespread. Or it may issue decisions that the parties ignore or that have no legal or political impact. The core challenge that ICs face, therefore, is transforming formal legal authority into authority in fact, also known as de facto authority.

The distinctive structures and functions of ICs shape how this transformation occurs. ICs "pre-exist the question that is to be decided," in that judges are selected "through a mechanism that does not depend on the will of the litigating parties." International judges also "sit on the body's bench and decide a series of cases," and their competence "derives from a public mandate [whose] outcome is, in essence, a public good." "Whereas diplomats strive for

1. See infra Part III.A.

2. Romano, Alter, and Shany state that ICs include six essential features:

1. international governmental organizations, or bodies and procedures of international governmental organizations that . .2. hear cases where one of the parties is, or could be, a state or an international organization; 3 . are composed of independent adjudicators, who ... 4. decide the question(s) brought before them on the basis of international law . . 5. following pre-determined rules of procedure, and ... 6. [that] issue binding decisions.

Cesare Romano, Karen J. Alter \& Yuval Shany, Mapping International Adjudicative Bodies, the Issues and Players, in OXFORD HANDBOOK OF INTERNATIONAL ADJUDICATION 1, 6 (Cesare Romano, Karen J. Alter \& Yuval Shany eds., 2014) [hereinafter OXFORD HANDBOOK].

3. See Andrei Marmor, An Institutional Conception of Authority, 39 PHIL. \& PUB. AFF. 238-40, 240 n.3 (2011).

4. Observers may differ over the precise boundaries of an IC's jurisdiction, but most agree that the act of delegation confers upon a court a circumscribed power to rule on disputes that fall within its jurisdiction. See generally Curtis A. Bradley \& Judith G. Kelley, The Concept of Delegation, 71 LAW \& CONTEMP. PROBS., no. 1, 2008 (discussing limits on international delegations).

5. Romano, Alter \& Shany, supra note 2, at 5.

6. Id. IC decisions are public goods in the sense that they further public goals. 
political compromise and arbitrators typically broker sustainable deals between the parties to a dispute, international judges are put in place to decide cases based on the reasoned interpretation and application of international law. In addition, international judges must consider how their decisions will be understood not only by today's litigants, but also by potential future litigants and other legal actors who may be affected by their rulings. ${ }^{7}$

These considerations distinguish courts from nonjudicial institutions. Most adjudication involves a plaintiff asserting a legal wrong and a defendant who is allegedly responsible for that wrong. The judges respond to the parties' claims by speaking what the law requires, that is, by assessing competing legal arguments, clarifying ambiguities, labeling violations, and perhaps specifying a remedy. The contrast between ICs and other international bodies is striking. Few expect the UN Security Council to deliberate, vote, or adopt legal edicts in the ways that domestic legislatures do. Yet government officials, lawyers, civil society groups, and actual or potential litigants expect ICs to act like domestic courts in the sense of following predetermined rules of procedure and justifying their decisions on the basis of legal reasoning and argumentation. These similarities suggest one way for ICs to convert formal legal authority into authority in fact-by emulating their domestic counterparts and cultivating a constituency of legal professionals who act as litigants, scholars, judges, activists, politicians, and businessmen.

Yet there are also important differences between national and international courts that may impede the transformation of an IC's authority from de jure authority to authority in fact. ICs are often new institutions. As such, their rulings may conflict with, and seek to displace, well-established or assumed interpretations of legal rules or social norms. Displacing entrenched ideas and practices is always difficult. For international judges, doing so is especially challenging because ICs operate in a context of multiple authoritative decisionmakers. Formally, most ICs are the highest judicial interpreters of the international rules within their respective jurisdictions. In practice, however, other international and domestic legal and political actors may compete over their respective jurisdictions and over the meanings of legal texts.

Domestic legal systems also have multiple levels of governance, but there is usually a shared understanding about which actors have the final word. ${ }^{8}$ In the United States, for example, federal legislative power coexists with state and local power, but established rules and procedures determine when state law must give way to federal law, and vice versa. ICs, by contrast, operate within a

7. Karen J. Alter, The NeW Terrain of InTERnational LaW: Courts, Politics, Rights 8-10 (2014) [hereinafter NEW TERRAIN].

8. See generally, e.g., Mireille Delmas-Marty, Ordering Pluralism: A Conceptual FRAMEWORK FOR UNDERSTANDING THE TRANSNATIONAL LEGAL WORLD (2009) (discussing the issue of multiple authorities as a focus of debates over legal pluralism and legal polycentricity); Liesbet Hooghe \& Gary Marks, Unraveling the Central State, but How? Types of Multi-level Governance, 97 AM. POL. SCI. REV. 233 (2003) (discussing a range hierarchical and non-hierarchical multi-level governance forms). 
context of international regime complexity that features "nested, partially overlapping, and parallel international regimes that are not hierarchically ordered." This lack of a clearly established hierarchy arises because states often draft new treaties and create new institutions without specifying their relationship to preexisting ones, and because many treaties give national governments discretion to decide how to implement international obligations. ${ }^{10}$ The result is that multiple actors within nested and parallel regimes can plausibly claim supremacy over overlapping legal domains.

The plurality of authoritative institutions and decisionmakers also shapes the understandings and expectations of domestic audiences. There are many reasons that ICs may fail to meet these understandings and expectations. Lawyers, government officials, NGOs, and academics often have deeply held ideas about national sovereignty, the place of international law in national legal orders, and the content of international rules. Some of these actors may not understand an IC's formal authority, may see IC rulings as strange and foreign, or may believe that IC rulings have no domestic legal effect. Divergences in legal practices among member states complicate this picture, because an IC's choice of one national practice or creation of a hybrid practice may introduce unfamiliar concepts to audiences in other countries. As entrenched as these ideas and practices may be, they must sometimes be displaced before domestic audiences will accept an IC's de facto authority. The essential point linking these examples is that actors can insist that they respect the rule of law and, at the same time, disregard IC rulings by relying on competing authoritative legal interpretations.

\section{III}

\section{THE VARIABLE AUTHORITY OF ICS}

This part explains how we ascertain IC authority in fact, operationalizing the concept by reference to the practices of different audiences that interact with ICs. Our goal is to create a practicable definition that reflects the real world in which ICs operate. We specify varying types of de facto authority that enable comparisons within a single court in different issue areas or over time, as well as between ICs. We conclude by identifying the indicators that we expect to observe when a court possesses different types of authority in fact.

9. Karen J. Alter \& Sophie Meunier, The Politics of International Regime Complexity, 7 PERSP. ON POL. 13, 13 (2009).

10. To domestic observers, this cacophony may appear as inefficient as it is convoluted. Yet scholars of international institutions have identified a number of advantages to maintaining this complexity. Robert O. Keohane and David G. Victor, for example, argue that a complex of climate change regimes is actually a better outcome than a single international climate change regime. Robert O. Keohane \& David G. Victor, The Regime Complex for Climate Change, 9 PERSP. ON POL. 7, 7 (2011). See also Hooghe \& Marks, Unraveling the Central State, supra note 8, at 235-39 (discussing the benefits of flexible governance models). 


\section{A. The De Facto Authority of ICs}

Many scholars analyze ICs by evaluating the particular design features of courts, by reviewing the quality of their reasoning, or by measuring state compliance with their decisions. ${ }^{11}$ In contrast, we assess the de facto authority of ICs by examining the practices of key audiences. Judges control neither the sword nor the purse. They cannot coerce litigants or other actors to behave in particular ways. Instead, ICs issue decisions that identify violations of international rules and create a legally binding obligation to comply with the court's judgments interpreting those rules. Whether such compliance actually occurs, however, depends upon the responses of the different audiences described in part III.B. ${ }^{12}$

We are interested in the statements and conduct of these audiences. In particular, we ask whether one or more audiences recognize, by their words, actions, or both, that IC rulings are legally binding and engage in actions that push toward giving full effect to those rulings. To facilitate comparisons within and across ICs, this metric is intentionally simple. While the empirical articles in the symposium do consider motives and reasons, our metric of authority, which measures observed practices, is agnostic as to why an audience recognizes a court's authority and to the subjective beliefs that underlie that recognition. Our approach thereby differs from what sometimes is labeled as sociological legitimacy, which focuses on how actors' perceptions may legitimize courts or how such perceptions allow courts to justify their practices and power. ${ }^{13}$

Perhaps most importantly, we do not ask whether IC authority is normatively legitimate. We are not alone in separating authority from legitimacy. Recent scholarship on international institutions also counsels against conflating the two concepts. ${ }^{14} \mathrm{We}$ defend this separation on the following grounds. First, ICs have an express legal competence usually based on a consensual act of delegation from states. ${ }^{15}$ For this reason, their legal right to rule is generally less contentious than that of other international institutions whose decisions purport to bind states. Second, we seek a straightforward and measurable yardstick to evaluate how a range of contextual factors shapes de facto authority of ICs via an analysis of audiences' practices toward ICs.

11. See, e.g., Karen J. Alter, The Global Spread of European Style International Courts, 35 West Eur. Pol. 135, 135 (2012).

12. This approach follows Andrei Marmor and Michael Zurn et al., who ask whether international institutions meet the empirical condition of actually having authority. See Andrei Marmor, supra note 3, at 252-55; Michael Zurn, Martin Binder \& Matthias Ecker-Ehrhardt, International Authority and its Politicization, 4 INT'L THEORY 69, 74 (2012).

13. See Mikael R. Madsen, Sociological Approaches to International Courts, in OXFORD HANDBOOK, supra note 2, at 388, 392-93 (discussing the difference between perception and justification, on the one hand, and practices and authority, on the other).

14. Birgit Peters \& Johan Karlsson Schaffer, The Turn to Authority Beyond States, 4 TransnAT'L LEGAL THEORY 315, 316 (2013); Marmor, supra note 3, at 238; Zurn, supra note 12, at 70, 73.

15. The International Criminal Tribunal for Rwanda and the International Criminal Tribunal for the former Yugoslavia, created pursuant to the Security Council's powers under Chapter VII of the UN Charter, are exceptions to the formal state consent to the act of delegation that establishes an IC. 
Although it is interesting to study subjective motivations and reasons why actors accept or reject IC rulings, observing practices does not necessarily shed light on this question. ${ }^{16}$ Third, and perhaps most fundamentally, we agree with Peters and Schaffer that

[m]any conceptions of authority link it so closely to legitimacy as to make "legitimate authority" tautological, and the two notions virtually indistinguishable. However, embedding legitimacy in the definition of authority may be both analytically and empirically problematic, especially if you want to theorize how international authority relates to resistance, mobilization and contestation.... First, if legitimacy and authority are two sides of a coin, then the more authority an institution has, the more legitimate it must be. This runs counter to experience: sometimes institutions acquire authority over new issues without necessarily being seen as more legitimate by all actors. Second, the [conflation of authority and legitimacy] seems to deny the existence of illegitimate authority - which might seem troubling for both normative and conceptual reasons ....

Applying this insight to ICs, we thus recognize that a court can do everything normative theorists might expect of a legitimate international judicial body and still not have authority in fact. The converse scenarioauthority in fact, without normative legitimacy — is also possible.

Our measure of de facto IC authority has two key components-(1) recognizing an obligation to comply with court rulings and (2) engaging in meaningful action pushing toward giving full effect to those rulings. This is a conjunctive standard that is assessed by examining the practices of the relevant actors. ${ }^{18}$ A simple public statement that a judgment is legally binding is, without more, inadequate. Equally insufficient is conduct that happens to conform to a judgment.

For states that are the defendants in most IC litigation, the recognition element can be either an express statement of intent to comply, or the implied acceptance that accompanies a government's decision to implement or give effect to a court's judgment. For non-parties, such as civil society groups or opposition politicians, recognition occurs when actors refer to IC decisions as legally binding when pushing states to conform to the court's judgment.

The meaningful action element is more difficult to gauge. For the losing state, full adherence to an IC judgment is, of course, sufficient. But it is also too exacting. Many international judicial rulings involve complex issues of law and policy that implicate different branches or levels of government-executive,

16. Focusing on practices avoids the obvious problem of how to measure subjective perceptions and motivations that cannot be directly observed. There may well be discrepancies between actors' internal, subjective views of IC decisions and the externally observable actions taken by, for example, government officials.

17. Peters \& Schaffer, supra note 14, at 334 (discussing Zurn, Binder \& Ecker-Ehrhardt, supra note 12$)$.

18. To reiterate, we are observing behavior-what actors do-without questioning the motivation or reason for their actions. If an actor demonstrates some recognition of an obligation to comply, the first criteria is met. We do not inquire into the deeper normative and constitutive forces that may contribute to this recognition. 
legislative, and judicial; national, state, and local. ${ }^{19}$ Coordinating responses among these multiple actors can be difficult, time-consuming, and sometimes impossible. In addition, many IC rulings may require social mobilization to be given full effect. To take account of these complex realities, our framework not only considers the practices of the litigants but also those of a wider set of participants in the legal process. For example, actors who are not a party to the dispute-such as NGOs, bar associations, and scholars-take meaningful action when they identify the specific steps needed to implement a judgment, or when they urge governments to change their behavior to preempt future IC litigation.

The response to the 2004 International Court of Justice (ICJ) judgment in the Avena case illustrates these complexities and further clarifies our dual criteria for IC de facto authority. In Avena, the ICJ ordered the United States to provide "review and reconsideration" of the convictions and sentences of fifty-one Mexican nationals on death row whose consular rights it had violated. ${ }^{20}$ The United States disagreed with the ICJ's interpretation of the Vienna Convention on Consular Rights and the remedies the Court ordered. Indeed, the United States withdrew its consent to ICJ jurisdiction to hear future disputes relating to the Vienna Convention. ${ }^{21}$ Yet President George W. Bush also issued a "memorandum" asserting that "the United States will discharge its international obligations under [the Avena judgment] by having State courts give effect to the decision ... in cases filed by the [fifty-one] Mexican nationals addressed in that decision." 22

We view President Bush's directive to state courts as both a consequential step toward compliance and a recognition of the ICJ's authority. We do so notwithstanding the fact that the U.S. Supreme Court later held that the Avena judgment was legally binding only at the international level and that the President's directive was unconstitutional. ${ }^{23}$ The Supreme Court's decision prevented all fifty-one Mexican nationals from receiving automatic review and reconsideration of their convictions and sentences. Nevertheless, a few state courts and officials have relied on Avena to grant such relief and to commute the death sentence of at least one defendant. ${ }^{24}$

19. See, e.g., Alexandra Huneeus, Courts Resisting Courts: Lessons from the Inter-American Court's Struggle to Enforce Human Rights, 44 CORNELL INT'L L.J. 493, 508 (2011) [hereinafter Courts Resisting Courts] (noting inverse correlation between number of branches of government involved in injunctive order and implementation of IC decision).

20. Case Concerning Avena and Other Mexican Nationals (Mexico v. United States of America), Judgment, 2004 I.C.J. Rep. 559, II 121 (Mar. 31).

21. Adam Liptak, U.S. Says It Has Withdrawn From World Judicial Body, N.Y. TIMES, Mar. 10, 2005, at A16.

22. Memorandum from President George W. Bush for Attorney Gen. Alberto R. Gonzales (Feb. 28, 2005), http://georgewbush-whitehouse.archives.gov/news/releases/2005/02/20050228-18.html.

23. Medellín v. Texas, 552 U.S. 491, 498-99 (2008). According to the Supreme Court, only a federal statute could compel state courts to comply with the ICJ judgment. Id. at 496. The Avena Case Implementation Act of 2008, H.R. 6481, 110th Cong. (2008) and other bills introduced to require compliance have yet to be enacted by Congress.

24. See Gutierrez v. State, No. 53506, 2012 WL 4355518, at*1 (Nev. Sept. 19, 2012); see also Sandra Babcock, The Limits of International Law: Efforts to Enforce Rulings of the International Court 
Although the ICJ's judgment is more than a decade old, we may not have seen the final act in the Avena saga. The Avena ruling has influenced behavior beyond the individuals directly implicated by the case. The federal government has taken steps to improve compliance with the consular notifications by state and local officials. ${ }^{25}$ And Congress may yet enact legislation to implement the ICJ's interpretation of the Vienna Convention, an outcome urged by scholars and by the Council of Europe that would bring the United States into full compliance, but without addressing the fact that the convictions of some Avena litigants were not reviewed prior to their execution. ${ }^{26}$

This example nicely illustrates that IC authority can exist notwithstanding disagreements about compliance among different branches or levels of government, and even in the face of overt rejections of IC rulings by some domestic actors. It also highlights the challenges of analyzing IC authority in the short term. Some will conclude from this discussion that the ICs we view as authoritative have only minimal legal and political influence. We return to this issue in part $\mathrm{V}$.

\section{B. IC Authority Assessed by the Practices of Different Audiences}

Our framework identifies five types of de facto authority that correspond to the practices of different IC audiences, which we illustrate with examples from this symposium. The first type is no authority in fact. Courts with no authority in fact have formal jurisdiction from the initial act of delegation, but, despite identified violations, litigants do not file complaints with the IC, and cases that the court does decide are generally ignored. For example, Gathii finds that the East African Court of Justice (EACJ) currently has no de facto authority among businesses, traders, and other economic actors in the East African Community, an audience envisioned as one of the court's principal constituencies. ${ }^{27}$

of Justice in U.S. Death Penalty Cases, 62 SYRACUSE L. REV. 183, 187-93 (2012) (discussing case law).

25. See, e.g., U.S. DEPARTMENT OF STATE, THE CONSUlar NotificATION AND ACCESS MANUAL 43 (4th ed. 2014), http://travel.state.gov/content/dam/travel/CNAtrainingresources/CNA Manual_Feb2014.pdf (instructing federal, state, and local law enforcement officials on actions required to comply with the VCCR "to ensure that the United States meets its international obligations").

26. Avena Case Implementation Act of 2008, H.R. 6481, 110th Cong., https://www.govtrack.us/congress/bills/110/hr6481; see also Jacob Katz Kogan, ASIL Presidents Call on Congress to Pass Legislation to Ensure Compliance with the Avena Judgment, INTERNATIONAL LAW REPORTER (July 18, 2008, 12:42 PM), http://ilreports.blogspot.com/2008/07/asil-presidents-call-oncongress-to.html; Council of Europe, The death penalty in Council of Europe member and observer states: a violation of human rights (Jan. 3, 2011) (urging the U.S. Congress to "pass legislation enabling those Mexican nationals condemned to death without having been provided with the consular assistance . . . to be retried following the correct procedures"), http://assembly.coe.int/nw/xml/XRef/ Xref-XML2HTML-en.asp?fileid=12590\&lang=en.

27. Gathii's conclusion is based on interviews with potential EACJ business interlocutors who noted widespread violations of EAC economic rules but see the court as unhelpful in addressing these violations. In Gathii's view, the lack of final EACJ decisions relevant to private businesses does not meet our definition of narrow authority. James Thuo Gathii, Variation in the Use of Subregional Integration Courts between Business and Human Rights Actors: The Case of the East African Court of Justice, 79 LAW \& CONTEMP. PROBS., no. 1, 2016, at 60-61. 
The second type, narrow authority, exists when only the parties to a particular dispute take meaningful steps toward compliance with a court's ruling. Narrow legal authority meets the minimum conditions for IC authority in fact-the recognition of a legal obligation and the need for a consequential response. The court's authority remains limited, however, because it does not extend beyond the litigants to the dispute. As Caserta and Madsen explain regarding the early rulings of the Caribbean Court of Justice (CCJ) interpreting CARICOM law, only the parties to individual cases recognized the court's decisions as legally binding and as requiring consequential steps toward compliance. ${ }^{28}$

Narrow authority falls short of what most observers expect of a courtnamely, the ability to cast a larger legal shadow that affects the behavior and decisions of other similarly-situated actors. A court achieves intermediate legal authority only when those actors also recognize the two elements of IC authority described above. The audiences in this intermediate range of authority include potential future litigants as well as government officials charged with implementing international rules as interpreted by the court, such as executive branch officials, administrative agency officials, and judges. This audience collectively constitutes what Alter labels as an IC's "compliance partners"- the actors who have the power to decide whether to comply with international law as interpreted by the IC. ${ }^{29}$

IC influence becomes more politically consequential at this stage. Our conception of intermediate authority resembles Marmor's idea of "practical authority," defined as the power "to determine, within a certain range of options, what types of normative change [an international institution] can introduce, how to make those changes, who is subject to them, often also how to monitor compliance, and how to respond to non-compliance. ${ }^{30}$ Such authority can exist even if the subject matter of adjudicated cases remains highly circumscribed. For example, Dickerson explains that the Organization for the Harmonization of Commercial Law in Africa (OHADA) Court, which interprets uniform regional commercial laws in West Africa, has intermediate authority vis-à-vis a subset of firms that operate in the formal economy and resolve their business disputes before the OHADA Court or in the shadow of the law as interpreted by the Court.

The third category, extensive authority, exists when an IC's audience expands beyond its compliance partners to encompass a broader range of actors, including civil society groups, bar associations, industries, and legal academics. ICs with extensive authority consistently shape law and politics for one or more legal issues within their jurisdiction. This level of authority is

28. Salvatore Caserta \& Mikael Rask Madsen, Between Community Law and Common Law: The Rise of the Caribbean Court of Justice at the Intersection of Regional Integration and Post-Colonial Legacies, 79 LAW \& CONTEMP. PROBS., no. 1, 2016, at 103-08.

29. Alter, NeW TERRAin, supra note 7, at 53.

30. Marmor, supra note 3 at 243. 
largely analogous to Pierre Bourdieu's notion of a "legal field"-the space where diverse actors accept the legal force of the law but may contest the meaning, legitimacy, and importance of different interpretations of the law. ${ }^{31}$ Applied to our object of inquiry, extensive authority is recognized in the practices of this wider audience. Yet although these actors acknowledge the court and its rulings as authoritative, they may still contest the precise meaning of the law.

One version of extensive authority is captured by the "island of effective international adjudication," built by the Andean Tribunal of Justice (ATJ), in the intellectual property (IP) issue area. According to Helfer, Alter, and Guerzovich, the ATJ has extensive authority over IP disputes because the practices of a wide range of actors - the industries that depend on IP rights; the businesses that litigate IP disputes; and the lawyers, domestic agencies, national judges, and legal scholars who specialize in IP-reveal habitual acceptance of ATJ rulings interpreting Andean IP law. ${ }^{32}$ Very different examples of extensive authority are the European Court of Justice (ECJ) and the European Court of Human Rights (ECtHR), discussed by Kelemen and Madsen in this issue. ${ }^{33}$ These courts consistently shape law and politics across most of their respective issue area domains and the states parties subject to their jurisdiction. We return to this topic in part IV.

A final level-one that we do not consider in this symposium-is popular authority, which exists when recognition of IC rulings extends beyond the legal field to encompass the public in general. ${ }^{34}$ Given their relatively young age, new

31. Bourdieu does not argue that legitimacy exists within a legal field. Rather, his primary claim is that within this field, actors with different interests, viewpoints, and power-endowments struggle to impose their preferred definition of legitimacy. Pierre Bourdieu, The Force of Law: Toward a Sociology of the Juridical Field, 38 HAstings L.J. 805-53 (1987); Yves Dezalay \& Mikael R. Madsen, The Force of Law and Lawyers: Pierre Bourdieu and the Reflexive Sociology of Law, 8 ANN. REV. L. AND SOC. SCI. 433, 435 (2012).

32. Laurence R. Helfer, Karen J. Alter \& M. Florencia Guerzovich, Islands of Effective International Adjudication: Constructing an Intellectual Property Rule of Law in the Andean Community, 103 AM. J. INT'L L. 1, 3 (2009). In other legal domains within the ATJ's jurisdiction, however, the Tribunal has, at best, narrow authority. It has issued far fewer rulings and has failed to develop relationships with potential litigants and compliance partners. Laurence R. Helfer \& Karen J. Alter, The Andean Tribunal of Justice and its Interlocutors: Understanding the Preliminary Ruling Reference Patterns in the Andean Community, 41 N.Y.U. J. INT'L L. \& POL. 871, 897-900 (2009).

33. R. Daniel Kelemen, The Court of Justice of the European Union in the Twenty-First Century, 79 LAW \& CONTEMP. PROBS., no. 1, 2016, at 117; Mikael Rask Madsen, The Challenging Authority of the European Court of Human Rights: From Cold War Legal Diplomacy to the Brighton Declaration and Backlash, 79 LAw \& CONTEMP. PROBS., no. 1, 2016, at 141.

34. Constitutional and supreme courts in both Germany and the United States arguably enjoy such popular authority. There are no studies of IC popular authority using our metrics. Existing studies focus on the relationship between public opinion and legitimacy, finding that some high courts garner more positive public feelings than national legislatures or executives. See, e.g., Gregory A. Caldeira, James L. Gibson \& Vanessa A. Baird, On the Legitimacy of National High Courts, 92 AM. POL. SCI. REV. 343, 343 (1998). For studies of public support for ICs, see generally Erik Voeten, Public Opinion and the Legitimacy of International Courts, 14 THEORETICAL INQUIRIES L. 411 (2013); Linda Camp Keith, Banks Miller \& Rachel McGuire, Second-Order Evaluations of the European Court of Human Rights, 3 J. L. \& COURTS 67 (2015). 
ICs are yet to reach the stage where publics understand, let alone recognize, the authority of ICs. Moreover, the specialized mandates of some courts may limit the extent to which publics ever recognize IC authority.

Figure 1 illustrates the levels of IC authority that are our primary focus. The white outer circle represents the court's de jure authority as specified via a formal act of delegation. This delegation is a precondition for the existence of any type of authority in fact. When an IC has no narrow, intermediate, or extensive de facto authority - that is, when no audience recognizes IC rulings as obligatory or undertakes meaningful actions that push toward compliance with the ruling - there would be no shaded circles within the outer white circle.

Figure 1 displays the three levels of de facto authority as nested, suggesting that a court first gains narrow, then intermediate, then extensive authority. But as we explain in the discussion that follows, we intend no teleology by this diagram. The three circles of de facto authority may not be nested; an IC could have extensive authority but lack narrow and intermediate authority. This is arguably the case for the International Criminal Court (ICC) and for the OHADA Court, as discussed by, respectively, Vinjamuri and Dickerson in this symposium. ${ }^{35}$ We also accept that IC authority can contract as well as expanda prospect that Shaffer, Elsig, and Puig highlight in their study of the World Trade Organization (WTO) Appellate Body's "extensive but fragile" authority, ${ }^{36}$ and one that Madsen addresses when he discusses recent debates and reforms of the ECtHR. ${ }^{37}$

35. Claire Moore Dickerson, The OHADA Common Court of Justice and Arbitration: Exogenous Forces Contributing to Its Influence, 79 LAW \& CONTEMP. PROBS., no. 1, 2016, at 63; Leslie Vinjamuri, The International Criminal Court and the Paradox of Authority, 79 LAW \& CONTEMP. PROBS., no. 1, 2016, at 275. Another example of intermediate authority without narrow authority is Ireland's modification of its prisoner voting laws in response to a politically contentious ECtHR judgment against the United Kingdom, which has publicly rejected the judgment and refused to comply. Laurence R. Helfer \& Erik Voeten, International Courts as Agents of Legal Change: Evidence from LGBT Rights in Europe, 68 INT'L ORG. 77, 83 (2014).

36. Gregory Shaffer, Manfred Elsig \& Sergio Puig, The Extensive (but Fragile) Authority of the WTO Appellate Body, 79 LAW \& CONTEMP. PROBS., no. 1, 2016, at 237.

37. Madsen, supra note 33, at 167-75. 
Figure 1: Three Types of Authority In Fact

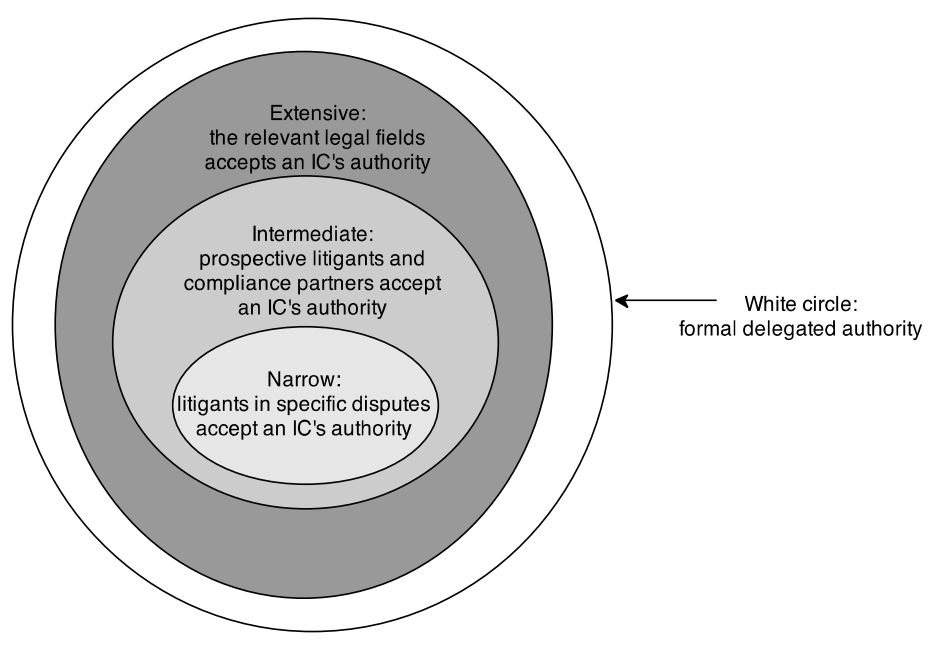

\section{Indicators of IC Authority In Fact}

This subpart identifies indicators of whether an IC has narrow, intermediate, extensive authority, or some combination thereof, using examples from different courts and types of cases. The empirical articles in the symposium explore many other indicators. Pinpointing the precise level of authority matters less for our framework than identifying movement across the types and variation within and across ICs.

Indicators of narrow legal authority: If the losing party publicly acknowledges an obligation to comply with an IC ruling, narrow legal authority is likely satisfied. The requirement for a consequential response is met by taking some meaningful step in response to the ruling, such as paying compensation, reviewing or revising challenged laws and policies, reopening judicial proceedings, and so forth. We leave open the time frame for these actions and accept that different actors, branches, or levels of government may disagree about what compliance with an IC ruling entails. ${ }^{38}$

Indicators of intermediate authority: IC authority remains narrow if, notwithstanding compliance in individual cases, there is general disregard for international rules and few adversely affected actors bother to challenge this

38. For example, in 2014 the ICJ issued judgments against Japan, involving a treaty banning commercial whaling, and against Chile concerning its maritime boundary with Peru. Political leaders in both countries publicly professed their intent to comply, albeit gradually, in the case against Chile and only partially in the suit against Japan. Martin Facklerapril, Japan Plans to Resume Whaling Program, With Changes to Address Court Concerns, N.Y. TIMES (Apr. 18, 2014), http://www.nytimes.com/2014/04 /19/world/asia/japan-says-it-will-resume-whaling-off-antarctica.html?_r=0; Ryan Dube, Peru, Chile Agree to 'Gradually' Implement Sea-Border Ruling, WALL ST. J. (Jan. 30, 2014), http://www.wsj.com/ articles/SB10001424052702304428004579353071019333430. 
noncompliance in court. Evidence that multiple litigants are filing complaints suggests the beginnings of intermediate authority because it indicates that a wider group of actors recognizes the IC as a forum to promote their legal rights.

Intermediate authority is solidified when IC rulings influence the behavior of potential litigants in similar cases. This is indicated by the revision of laws and practices to preempt litigation as well as a court's lengthening shadow in discussions among lawyers and clients. For example, Huneeus explains that Colombian officials anticipated what the Inter-American Court might rule regarding an indigenous land rights case, and Colombian judges regularly refer to Inter-American Court jurisprudence when considering cases involving criminal, family, and administrative law. ${ }^{39}$ Scholars have observed similar patterns in the ECJ and the ECtHR. ${ }^{40}$

Indicators of extensive authority: For ICs with extensive authority, one often finds textbooks and scholarly treatises on IC case law; an established bar that appears before the court; NGOs using international litigation; and a diverse range of judges, practitioners, and officials who draw on IC jurisprudence in their day-to-day activities. Extensive authority is also revealed by the regular invocation of IC decisions or potential litigation in legal and policy discussions, with government officials referencing the prospects of IC review as they debate and develop policy proposals. Extensive authority often requires that an IC fulfill the requirements of narrow and intermediate authority. But extensive authority does not require universal acquiescence; it is compatible not only with the rejection of authority in fact by some litigants but also with resistance to such authority, a reality that that Vinjamuri discusses in her analysis of the ICC's authority. ${ }^{41}$

Legal fields are characterized by contestations of ideas and clashes of power and interests. Indeed, the more an international institution exercises its right to make collectively binding decisions, the more likely it will engender politicized disagreement. ${ }^{42}$ As applied to ICs, this insight may be reflected in the rejection of narrow or intermediate authority by some litigants for a court that has otherwise made an indelible mark on a legal field. For example, Shaffer, Elsig, and Puig explain how a wide range of actors in the legal field of international trade law-including trade ministry officials, industry associations, law firms,

39. Alexandra Huneeus, Constitutional Lawyers and the Inter-American Court's Varied Authority, 79 LAW \& CONTEMP. PROBS., no. 1, 2016, at 191 [hereinafter Constitutional Lawyers].

40. For examples of states that preemptively modified their laws and policies following rulings from these ICs against other states that had adopted similar laws and policies, see, for example., RACHEl Cichowski, THE European COURT AND Civil SocieTY: Litigation, Mobilization AND GOVERNANCE 17-23 (2007); Helfer \& Voeten, supra note 35, at 81. Regarding the ECtHR, British authorities already in the 1980s started screening all new legislation for compliance with the European Convention of Human Rights to avoid new cases in Strasbourg. Mikael Rask Madsen, France, the UK and "Boomerang" of the Internationalization of Human Rights (1945-2000), in HUMAN Rights Brought Home: Socio-Legal Perspectives on Human Rights in the National CONTEXT 57, 81 (Simon Halliday \& Patrick Schmidt eds., 2004).

41. Vinjamuri, supra note 35, at 281-83.

42. See Zurn et al., supra note 12 , at $87-88$. 
and scholars-quickly recognized WTO Appellate Body rulings as authoritative, even as some governments continued to enact domestic laws that unquestionably violate WTO rules. ${ }^{43}$ Extensive authority does, however, help international judges weather even heated contestations about specific rulings, such as the resistance to the ECJ by Hungary's increasingly authoritarian government that Kelemen describes. ${ }^{44}$

We asked our contributors to compare the authority of ICs across time, actors, or the legal domains that fall under the IC's formal jurisdiction. Table 1 summarizes the comparisons, and the corresponding types of authority. Perhaps most importantly, Table 1 reveals that IC authority is not static, and that ICs with extensive authority do not always have narrow or intermediate authority.

43. Shaffer, Elsig \& Puig, supra note 36, at 267-72.

44. Kelemen, supra note 33, at 131; see also Madsen, supra note 33, at 167-75 (discussing the ECtHR and the challenges it is facing, particularly in Russia). 
Table 1: Comparisons of IC Authority In Fact across Contexts

\begin{tabular}{|c|c|c|}
\hline EACJ & $\begin{array}{l}\text { Economic law } \\
\text { No authority in fact }\end{array}$ & $\begin{array}{l}\text { Human rights law } \\
\text { Emerging extensive authority absent } \\
\text { intermediate authority }\end{array}$ \\
\hline $\begin{array}{c}\text { OHADA } \\
\text { Court }\end{array}$ & $\begin{array}{l}\text { Formal economy } \\
\text { Narrow, intermediate, and extensive } \\
\text { authority at a thin elite level }\end{array}$ & $\begin{array}{l}\text { Informal economy } \\
\text { No authority in fact }\end{array}$ \\
\hline CCJ & $\begin{array}{l}\text { Founding period (2005-2010) } \\
\text { Narrow authority for CARICOM cases; } \\
\text { intermediate authority for appeals of } \\
\text { national rulings. }\end{array}$ & $\begin{array}{l}\text { Recent period (2011-2014) } \\
\text { Emerging intermediate and extensive } \\
\text { authority for CARICOM cases and } \\
\text { appeals of national rulings }\end{array}$ \\
\hline ECJ & $\begin{array}{l}\text { Pre-enlargement EU (1970s-1990s) } \\
\text { Narrow, intermediate, and extensive } \\
\text { authority }\end{array}$ & $\begin{array}{l}\text { Post-enlargement EU (2000-present) } \\
\text { Authority continues, but recent decrease } \\
\text { of narrow authority in few new accession } \\
\text { states }\end{array}$ \\
\hline ECtHR & $\begin{array}{l}\text { Cold War Era (1950s-1989) } \\
\text { Narrow and intermediate authority }\end{array}$ & $\begin{array}{l}\text { Post-Cold War Era (1990-2014) } \\
\text { Narrow and intermediate authority; } \\
\text { Extensive authority may be retracting in } \\
\text { some member states }\end{array}$ \\
\hline IACtHR & $\begin{array}{l}\text { Colombia } \\
\text { Narrow, intermediate, and extensive } \\
\text { authority }\end{array}$ & $\begin{array}{l}\text { Chile } \\
\text { Narrow and intermediate authority } \\
\text { Venezuela } \\
\text { Narrow authority to no authority in fact }\end{array}$ \\
\hline $\begin{array}{l}\text { ICJ } \\
\text { (vis-à-vis } \\
\text { Islamic law } \\
\text { states) }\end{array}$ & $\begin{array}{l}\text { Territorial disputes } \\
\text { Narrow authority in litigated cases }\end{array}$ & $\begin{array}{l}\text { Diplomatic immunity disputes } \\
\text { No authority in fact }\end{array}$ \\
\hline WTO & $\begin{array}{l}\text { GATT era } \\
\text { Narrow authority }\end{array}$ & $\begin{array}{l}\text { WTO era } \\
\text { Narrow, intermediate, and extensive } \\
\text { authority alongside growing fragility }\end{array}$ \\
\hline
\end{tabular}




\begin{tabular}{|c|l|l|}
\hline \multirow{2}{*}{ ICC } & $\begin{array}{l}\text { Self-referrals } \\
\text { Extensive authority without } \\
\text { intermediate authority; spotty narrow } \\
\text { authority }\end{array}$ & $\begin{array}{l}\text { Security Council \& proprio moto referrals } \\
\text { Extensive authority without intermediate } \\
\text { or narrow authority }\end{array}$ \\
\hline $\begin{array}{c}\text { International } \\
\text { Criminal } \\
\text { Tribunals } \\
\text { (ICTs) }\end{array}$ & $\begin{array}{l}\text { Nuremberg Tribunals } \\
\text { intermediate authority }\end{array}$ & $\begin{array}{l}\text { International Criminal Tribunal for the } \\
\text { Former Yugoslavia } \\
\text { Narrow authority and some intermediate } \\
\text { authority } \\
\text { International Criminal Court } \\
\text { Extensive authority alongside declining } \\
\text { narrow and intermediate authority }\end{array}$ \\
\end{tabular}

IV

\section{CONTEXTUAL FACTORS THAT SHAPE IC AUTHORITY}

We next turn to the contexts in which ICs operate. We are interested in how a range of contextual factors beyond the immediate control of judges influence the creation, expansion, or dissipation of IC legal authority. In particular, we ask how different contextual factors enable some courts to gain different levels of authority, whereas others with similar or different access rules, mandates, and supporters have no authority in fact, remain static, or even experience contractions in authority.

The discussion is divided into three analytically distinct categories. Institution-specific context captures features that are distinctive to a particular IC, such as its design and subject matter mandate. These features most often vary across courts, but there may also be variation within a single IC over time or across issue areas. Constituencies context analyzes issues related to IC interlocutors, including government officials, judges, attorneys, legal experts, and civil society groups. Global, regional, and local political context considers how political dynamics at these different levels affect IC authority. Given that the empirical articles in this symposium all analyze complex processes concerning multiple types of authority and specific levels of audiences and politics, our discussion is only illustrative rather than exhaustive and points to the overlap and interdependence across different categories of context. We first review the contextual factors in each category and then briefly consider how IC judges themselves may seek to influence these contextual factors.

\section{A. Institution-Specific Contexts}

Institution-specific contextual factors relate to a single IC and may impact the ways in which audiences relate to that court. We focus in particular on 
access rules and jurisdiction, alternatives to international litigation, and variations in subject matter mandates. Although distinctive to particular courts, these factors often vary across and within ICs in ways that may enhance or impede connections with different audiences.

\section{Access Rules and Jurisdiction}

The first permanent ICs were interstate dispute settlement bodies created to adjudicate conflicts between states with the consent of both parties. ${ }^{45}$ This model of international adjudication-what Alter has labeled "old style" ICsallows only states to initiate litigation, often only for a specific case or controversy. ${ }^{46}$ Old-style ICs today occupy a less prominent place in international adjudication than they did in previous decades, but they remain an important venue for some countries and in some issue areas, as illustrated by Powell's comparison of the differing authority of the ICJ-the canonical old-style court-in territorial and immunity disputes involving Islamic law states. ${ }^{47}$

Beginning after World War II, and accelerating at the end of the Cold War, states created new-style ICs whose compulsory jurisdiction is often a mandatory component of a treaty regime of which the court is an integral part. ${ }^{48}$ It is more difficult to block litigation when an IC has compulsory jurisdiction. Negotiations are thus more likely to take place in the shadow of adjudication, increasing the bargaining leverage of plaintiffs whose claims are supported by the law. Additionally, because plaintiffs can initiate litigation without the express consent of states, we expect ICs with compulsory jurisdiction to be busier. To the extent that the losing parties respect IC rulings against them, compulsory jurisdiction may help ICs gain narrow authority. Such jurisdiction may even be necessary for intermediate and extensive authority.

Multiple access points, especially for nonstate actors, are another hallmark of new style ICs. This design innovation was first introduced with the creation of the ECJ and the ECtHR, two European courts that have since served as models for economic and human rights courts in other regions. For the ECJstyle ICs, access points include preliminary references from lower and apex national courts, direct access by private parties, and the investigation and pursuit of complaints by commissions or secretariats. For the ECtHR-style tribunals, private litigants must first exhaust domestic remedies and then file international petitions, either directly with the IC or via the intermediary of a human rights commission. In addition, in both models states can, although

45. Mary Ellen O'Connell \& Lenore VanderZee, The History of International Adjudication, in OXFORD HANDBOOK, supra note 2, at 42, 55-58.

46. Alter, NeW TERRAin, supra note 7, at 83.

47. Emilia Justyna Powell, Islamic Law States and the Authority of the International Court of Justice: Territorial Sovereignty and Diplomatic Immunity, 79 LAW \& CONTEMP. PROBS., no. 1, 2016, at 209.

48. Alter, NeW Terrain, supra note 7, at 81-85; Cesare P. Romano, From the Consensual to the Compulsory Paradigm in International Adjudication: Elements for a Theory of Consent, 39 N.Y.U. J. INT’L L. \& POL. 791, 808-11 (2007). 
seldom do, initiate litigation against other countries alleging breaches of the relevant international agreements. ${ }^{49}$

Multiple access points expand the opportunities for ICs to acquire all three levels of authority in fact. When only governments choose whether to file suit, the decision to litigate is often influenced by political and diplomatic concerns unrelated to the merits of a case..$^{50}$ In addition, multiple access points allow nonstate actors-such as private litigants, supranational commissions, or prosecutors-to use IC litigation to circumvent domestic legal blockages. As a result, disputes that governments and national judges might prefer to handle quietly behind closed doors or reserve for future bargaining are more likely to see the light of day. Litigating these cases also allows ICs to "gain[] political capital from a growing caseload by demonstrably performing a needed function. ${ }^{" 51}$ The emergence of this positive feedback loop may be an indicator that an IC is developing intermediate authority.

The importance of access rules and jurisdiction is revealed when governments restructure ICs, widen their subject matter jurisdiction, or increase the number of state parties. A number of articles in this issue investigate the effect of IC design features and design changes. Shaffer, Elsig, and Puig compare the many blockages to dispute settlement under the General Agreement on Tariffs and Trade (GATT) with the WTO panels and Appellate Body, demonstrating that the GATT system struggled to develop narrow authority whereas the WTO system almost immediately gained extensive authority. ${ }^{52}$ Vinjamuri compares ICC cases referred by the UN Security Council to self-referrals by states and finds that the mode of referral neither enhances nor hinders the ICC's narrow authority in the case at hand..$^{53}$

\section{Alternatives to International Litigation}

Although wider access rules and jurisdiction are likely to increase the flow of cases to court, the existence of attractive alternatives to international litigation may siphon away cases and diminish opportunities to build connections to litigants and other audiences. The attractiveness of these alternatives varies widely across ICs. The more attractive the alternatives, the fewer cases a court is likely to receive and the less likely it can establish any level of authority in fact.

Alternative dispute resolution mechanisms, such as conciliation, negotiation,

49. Alter, NEW TERRAIN, supra note 7, at 87-94.

50. David A. Wirth, Reexamining Decision-Making Processes in International Environmental Law, 79 IOWA L. REV. 769, 779 (1994) ("Notwithstanding a meritorious legal claim . . ., one State may be reluctant to initiate a third-party dispute settlement process against another State for fear of jeopardizing other strategic or economic bilateral relationships.").

51. Robert Keohane, Andrew Moravcsik \& Anne-Marie Slaughter, Legalized Dispute Resolution: Interstate and Transnational, 54 INT'L ORG. 457, 482 (2000); see also Alec Stone Sweet, Judicialization and the Construction of Governance, 32 COMP. POL. STUDIES 147, 157 (1999) (discussing how switching from dyadic to trilateral dispute adjudication fuels norm creation).

52. Shaffer, Elsig \& Puig, supra note 36, at 241-55.

53. Vinjamuri, supra note 35 , at $280-86$. 
mediation, and arbitration, often offer appealing alternatives to international adjudication because they are generally faster, less formal, less expensive, and allow the parties to choose the decisionmakers and whether the decisions should be made public. ${ }^{54}$ These alternatives can accomplish litigant objectives, but their use can hinder the ability of ICs to gain de facto authority by interpreting legal rules and issuing public, reasoned assessments of the litigants' competing claims.

The attractiveness of litigation alternatives may also depend upon whether the party most likely to file suit is a state, a commission or prosecutor, or a private party. States involved in multiple disputes and policy negotiations may have greater room to negotiate out-of-court settlements. Private actors often have less bargaining leverage than public actors, but they too may have viable alternatives to IC litigation. Private actors may pursue cases in domestic courts or use political connections to broker a favorable resolution of disputes. For example, Gathii finds that such alternatives are the primary reason that businesses do not turn to the EACJ to challenge violations of East Africa Community free trade rules. ${ }^{55}$ If, however, domestic courts are sympathetic to governments or if private parties lack political connections, international adjudication may be the only viable option.

A different type of alternative exists for disputes that can be litigated before more than one IC. ${ }^{56}$ The ability to forum shop may enhance a plaintiff's negotiating leverage by allowing him or her to select a court that is more likely to rule favorably. The existence of multiple venues may also make it more difficult for any single IC to establish narrow or intermediate authority. ${ }^{57}$ In addition, prospective litigants and compliance partners may be wary of interacting with or shaping their behavior in response to an IC when other tribunals can opine on the meaning of the same or similar international rules but reach a different result. ${ }^{58}$

\section{Subject Matter Competence}

All other things equal, ICs have more opportunities to gain authority in fact when alternatives to litigation are few, the demand for international

54. See W. MichaEl REISMAN, SySTEMS OF CONTROL IN INTERNATIONAL AdJUDICATION AND ARBITRATION 46-106 (1992).

55. Gathii, supra note 27 , at 45-54.

56. Laurence R. Helfer, Forum Shopping for Human Rights, 148 U. PA. L. REV. 285, 289 (1999).

57. For example, maritime boundary disputes tend to be adjudicated by the ICJ, depriving the International Tribunal of the Law of the Sea of opportunities to develop its authority in this area. In addition, states sometimes relitigate cases decided in the MERCOSUR and NAFTA dispute settlement systems before WTO panels and the Appellate Body. See Joost Pauwelyn \& Luiz Eduard Salles, Forum Shopping Before International Tribunals: (Real) concerns, (Im)Possible solutions, 42 CORNELL INT'L L.J. 77, 77-79 (2009). In Africa, suits relating to Senegal's refusal to prosecute or extradite former Chadian President Hissein Habré have been filed before the African Court of Human and Peoples' Rights, the ECOWAS Court, and the ICJ. See Sangeeta Shah, Questions Relating to the Obligation to Prosecute or Extradite (Belgium v Senegal), 13 HUM. RTS. L. REV. 351, 354-56, 355 n.22 (2013).

58. Jacob Katz Cogan, Competition and Control in International Adjudication, 48 VA. J. INT'L L. 411, 440-44 (2008). 
adjudication is high, or both situations exist simultaneously. The attractiveness of these alternatives and the demand for litigation are likely to vary with the subject matter of the cases that an IC can hear. ${ }^{59}$

For some issue areas there may be overlapping and conflicting legal rules or multiple legal and political venues in which litigants can pursue their objectives. For example, Gathii, Caserta and Madsen, and Dickerson suggest that economic actors may have more alternatives to choose from, including political or informal means of resolving disputes. In contrast, Huneeus's analysis of the changing political climate in Latin America suggests that the options to remedy human rights violations are more limited. During the era of military dictatorships, and in Venezuela more recently, the Inter-American system was a plausible venue in which to pursue human rights complaints. Yet in countries with vibrant neoconstitutionalist movements, domestic judges and government officials often cite Inter-American rulings against other states to justify changes in their own laws and policies, preempting regional litigation and giving the IACtHR intermediate authority. ${ }^{60}$ For international criminal law, the goal of the international criminal system is to generate alternatives to ICC adjudication. Yet as Vinjamuri suggests, a lack of faith in the ICC may generate alternatives to ICC litigation that undermine a court's authority. ${ }^{61}$

Another way that subject matter may affect IC authority relates to the political salience of disputes. The dockets of some ICs are dominated by technical or low-politics cases primarily of interest to specialized groups of litigants, lawyers, and experts. ICs that adjudicate disputes about the ownership of patents, such as the ATJ, or the terms of private commercial contracts, the OHADA Court for example, may find it easier to gain narrow, intermediate, and extensive authority because few actors beyond the relevant specialized community scrutinize or contest their rulings. In contrast, ICs may have more difficulty gaining any de facto authority for high-politics disputes, such as those involving military force or systemic human rights abuses, because a wide range of actors, such as executive branch officials, are watching the court and have the incentive and the means to challenge rulings contrary to their interests.

Combining these institution-specific factors reveals a potential paradox. In low-politics cases, including many disputes over international economic rules, ICs may more easily achieve narrow or intermediate authority. Yet the abundance of alternatives available to address the concerns of businesses and lawyers can deprive ICs of cases needed to generate even narrow authority. For issue areas in which the political stakes are higher, in contrast, an IC may be the only available venue to raise legal violations, a reality that both attracts

59. Benedict Kingsbury, International Courts: Uneven Judicialization in Global Order, in CAMBRIDGE COMPANION TO INTERNATIONAL LAW 203, 212 (James Crawford \& Martti Koskenniemi eds., 2012).

60. See, e.g., Christina Binder, The Prohibition of Amnesties by the Inter-American Court of Human Rights, 12 GERMAN L.J. 1203, 1218-26 (2011).

61. Vinjamuri, supra note 35 , at 282-83. 
complainants yet also makes it more challenging to establish IC authority with respondent states.

\section{B. IC Constituencies and Their Varied Interests}

We next explain how different constellations of constituencies can assist or impede ICs from gaining narrow, intermediate, and extensive authority. We begin by disaggregating the state into key sub-state actors-such as government officials, national courts, and administrative agencies-and then discuss private IC interlocutors, including legal experts, businesses, and NGOs. Constituency support is a key determinant of IC authority. Observers tend to take the support of constituencies for granted when such support exists. In practice, it is the lack of support that constrains IC authority. Variation that is rooted in the constituencies themselves thus provides an implicit aid or hurdle to creating and building IC authority.

\section{Key Constituencies}

Executive branches. Some scholars expect that ICs will garner narrow and intermediate authority by catering to the interests of executive branches. ${ }^{62}$ It is certainly more difficult for ICs to gain narrow authority when litigating governments strongly contest IC rulings. An IC's disagreement with governments, however, is not always a problem. Executive officials sometimes dislike existing domestic laws or policies and thus may welcome IC rulings that order the end of those practices. The executive may also welcome losing a case when it can blame the court for disappointing domestic interest groups. Even when governments oppose a legal loss, an IC with extensive authority-and the support it thus enjoys from a wide audience-may make it more costly for executive officials to ignore or contest the ruling. Gathii makes this point, explaining that "human rights activists bring cases before the EACJ not necessarily or merely to get compliance, but to name and shame their governments for the alleged violations." ${ }^{63}$ Whether the executive accepts adverse legal outcomes can vary by type of government, by issue area, by a court's years of operation, and over time. This suggests that observers should pay careful attention to case-specific factors that explain variations in officials' interests in IC rulings. Vinjamuri makes this point as she assesses the changing interest of governments after they self-refer cases to the ICC. ${ }^{64}$

National courts are another key constituency for ICs. National judges interact with their international colleagues in multiple ways, including by referring cases to ECJ-style tribunals and by applying international law as interpreted by ICs in domestic litigation. Gaining support from national judges

62. Eric A. Posner \& Alan O. Sykes, Efficient Breach of International Law: Optimal Remedies, "Legalized Noncompliance," and Related Issues, 110 MICH. L. REV. 243, 280 (2011); Eric A. Posner \& John C. Yoo, A Theory of International Adjudication, 93 CALIF. L. REV. 1, 55-56 (2005).

63. Gathii, supra note 27, at 61.

64. Vinjamuri, supra note 35 , at $280-83$. 
may help ICs achieve intermediate authority by mobilizing compliance partners even when executive branch officials or legislators reject specific international rulings.

Extensive authority can be achieved only when IC jurisprudence is internalized by domestic legal constituencies-including national judges. As a formal matter, national judges may be obligated to refer certain cases or to apply international law as interpreted by an IC. When national judges habitually refer cases and apply IC rulings in these ways, it is tempting to assume that extensive authority exists. As we explained in part I, however, issues of hierarchy and legal culture complicate relations between international and national judges - in particular, the revision or displacement of existing legal practices. The more open national judiciaries are to such changes, the greater the likelihood that an IC can successfully establish intermediate and extensive authority.

This insight is reflected in several contributions to this issue. For example, Dickerson finds uneven awareness of OHADA law and the OHADA Court among national judges. ${ }^{65}$ More consistent awareness may be a precondition to changing domestic practices in commercial law disputes. Huneeus finds that national judges in "neoconstitutional" legal systems are more likely to recognize the IACtHR's authority to interpret legal norms common to human rights treaties and national constitutions than judges in other Latin American countries. ${ }^{66}$ Kelemen explores another variation, highlighting the impediments to judiciaries in Hungary, Bulgaria, and Romania serving as "Union courts" even as national judges in long-standing EU member states have readily accepted that role. ${ }^{67}$

National administrative agencies can also be an important constituency for ICs, especially when other national actors resist or ignore IC rulings. Certain conditions must be in place, however, for IC rulings to resonate with agency officials.

When administrators gain personally from violating the law-by accepting bribes or granting personal favors, for example-they have little reason to pay attention to IC decisions, making it all but impossible for the IC to gain narrow or intermediate authority. ${ }^{68}$ Administrators' willingness to act outside the law also provides a ready alternative to international litigation. When, in contrast, administrative agencies operate as professionalized technical bodies, ICs may build narrow and intermediate authority by validating agency interpretations of the law and by providing cover when administrative decisions disappoint influential clients. ICs can also build intermediate authority by filling gaps in legal texts and by addressing the practical problems that agency officials face.

65. Dickerson, supra note 35 , at 79

66. Huneeus, Constitutional Lawyers, supra note 39, at 187-201, 205-06.

67. Kelemen, supra note 33, at 136.

68. See, e.g., Helfer, Alter \& Guerzovich, supra note 32, at 24 (discussing the relationship between domestic administrative agencies and the ATJ). 
Legal experts, including practicing lawyers and legal academics, are often central to the development of IC authority. These actors are generally less constrained, both legally and politically, than government officials, national judges, and agency administrators. Practitioners are also formally shielded by canons of professional responsibility and might benefit regardless of which party prevails in a particular suit. ${ }^{69}$

Narrow or intermediate authority is often associated with a handful of legal practitioners who are frequent judicial interlocutors. In a number of instances, these institutional insiders helped to create or previously worked for the court before which they now appear, or they have professional connections to judges from participating in conferences and law teaching. ${ }^{70}$ In this symposium, Caserta and Madsen explain how this insider story was critical for the CCJ to gain narrow authority in its early original jurisdiction cases. ${ }^{71}$

When ICs become busier, they tend to generate a specialized bar of repeat players with field-specific knowledge who provide advice to governments, businesses, and private litigants. Shaffer, Elsig, and Puig observe that the WTO Appellate Body rapidly gained extensive authority in large part due to the support of trade law experts. ${ }^{72}$ Conversely, Vinjamuri observes that although the ICC appears to enjoy extensive authority within the community of international criminal law experts, it still struggles to gain a basic requisite of narrow authority-custody over indicted defendants-in many high-profile cases. $^{73}$

Civil society groups, which range from public interest NGOs to industry associations, are also important contributors to the enlargement of IC authority. Public interest NGOs often file test cases-especially before human rights tribunals - that invite international judges broadly to interpret treaty texts or to expand principles only hinted at in earlier rulings. ${ }^{74}$ Such groups also monitor suits filed by private litigants, often requesting leave to file amicus briefs that amplify legal arguments or the practical consequences of alternative rulings. NGOs also serve as nodes for coordinating medium- and long-term litigation

69. Mikael Rask Madsen, Reflexivity and the Construction of the International Object: The Case of Human Rights, 5 INT'L POL. SOC. 259, 269-71 (2011).

70. See generally KAREN J. ALTER, Jurist Advocacy Movements in Europe: The Role of Euro-Law Associations in European Integration (1953-1975) (2009), in THE EUROPEAN COURT'S POLITICAL POWER: SELECTED ESSAYS 63, 63-89 (2009); Stéphanie Hennette-Vauchez, The ECHR and the Birth of (European) Human Rights Law as an Academic Discipline, in LAWYERING EUROPE: EUROPEAN LAW AS a Transnational Social Field 117, 117-35 (Bruno de Witte \& Antoine Vauchez eds., 2013); Antoine Vauchez, Introduction. Euro-lawyering, Transnational Social Fields and European Polity-Building, in LAWYERING EuRoPe 1, 1-28 (Antoine Vauchez \& Bruno de Witte eds., 2013).

71. See Caserta \& Madsen, supra note 28, at 103-14.

72. Shaffer, Elsig \& Puig, supra note 36, at 243-47.

73. Vinjamuri, supra note 35 , at 281.

74. A concrete example is the Essex Human Rights Centre, which is one of the most active human rights law offices in Europe, especially with regard to Kurdish cases before the ECtHR. Rachel Cichowski, Civil Society and the European Court of Human Rights, in THE EUROPEAN COURT OF HUMAN RIGHTS BETWEEN LAW AND POLITICS 77, 86 (Jonas Christoffersen \& Mikael R. Madsen eds., 2011). 
strategies among litigants, attorneys, and sympathetic government officials who share similar interests and objectives.

In this symposium, Gathii finds that the EACJ is forging connections with human rights bar associations and civil society groups, ${ }^{75}$ and Huneeus discusses links between the IACtHR and neoconstitutionalist lawyers. ${ }^{76} \mathrm{NGO}$ advocacy can be a double-edged sword, however. Bold international decisions that endorse civil society arguments can build a profile among potential complainants, but they may also engender opposition from government officials and national judges who oppose such expansive rulings. A stark example, discussed by Huneeus, is Venezuela's 2013 withdrawal from the American Convention on Human Rights and the jurisdiction of the IACtHR. ${ }^{77}$

Whether businesses and firms contribute to building IC authority often depends upon cost-benefit calculations that weigh the risks of litigation against the risks of other dispute resolution options. Some ICs grant direct access to business actors to challenge violations of international economic law, but many ICs do not. Even when such access exists, firms engaged in transborder transactions are often deeply dependent on the cooperation of customs, tax agents, and other government officials, whom they therefore may be reluctant to sue even for flagrant violations of the law. As Caserta and Madsen explain, many private companies fear that they will face retaliation by Caribbean states in which they seek to do business if they file suits before the CCJ. ${ }^{78}$ In this environment, personal connections, negotiations, and other modes of dispute resolution are often far less risky.

\section{Constituencies and the Expansion of Authority}

ICs gain de facto authority through the iterative process of issuing decisions that key audiences recognize and respond to with consequential steps toward compliance. ${ }^{79}$ The foregoing discussion suggests, however, that the divergent interests of various IC constituencies may persist even if IC rulings are logically consistent and legally persuasive. These divergent interests suggest that there are multiple pathways for ICs to gain authority in fact. Some tribunals acquire intermediate legal authority when an entrepreneurial law firm or NGO decides to test the waters. For example, filing a complaint that triggers copy-cat cases may help a court develop its jurisprudence and connect with additional interlocutors. For other ICs, a pent-up demand for adjudication leads to a large number of early suits that create both opportunities and risks for international judges. ${ }^{80}$ For still other courts, complaints or referrals may come in fits and

75. Gathii, supra note 27, at 38, 43 n. 50 .

76. See generally Huneeus, Constitutional Lawyers, supra note 39.

77. Id. at 197-201.

78. Caserta \& Madsen, supra note 28 at 102.

79. Joseph Weiler, The Transformation of Europe, 100 YALE L.J. 2403, 2447-48 (1991) (discussing how the ECJ built its authority incrementally through its interactions with national judges, government officials, and private litigants).

80. This pattern exists in the Andean Community legal system. See Helfer \& Alter, supra note 32, 
starts until the judges develop relationships with the relevant constituencies.

Even in the best-case scenario, it takes time for different constituencies to view ICs as viable venues for adjudicating their claims. It should thus come as no surprise that newer ICs often have a harder time gaining narrow and intermediate authority compared to ICs where litigants can refer to past practices as they decide which suits to pursue. There is, however, one way in which today's nascent ICs may be advantaged compared to their predecessors. Older ICs generally operated in an informational vacuum and had to invent legal subject areas. Recently established courts, in contrast, can sometimes draw upon preexisting practices to more quickly establish their own de facto authority. In this symposium, Levi, Hagan, and Dezalay describe how the prosecutors for the International Criminal Tribunal for the former Yugoslavia drew inspiration from, yet expanded beyond, the prosecutorial strategies used during the Nuremburg trials. ${ }^{81}$ Shaffer, Elsig, and Puig find that the GATT dispute settlement panels, despite facing many obstacles, over time created a body of legal interpretations that aided the WTO Appellate Body in quickly establishing extensive authority. ${ }^{82}$ These examples illustrate a more general point: it should be easier for ICs to gain authority when legal subject areas are well developed because potential litigants and other interlocutors predate the court's creation. Vinjamuri's analysis, however, raises the cautionary point that mercurial government interests can impede criminal courts because international prosecutors depend on state support, which, when given, may anger and undermine the ICC's authority vis-à-vis other states. ${ }^{83}$

\section{Global, Regional, and Domestic Political Contexts}

This section considers how different political contexts help or hinder the creation and evolution of IC legal authority. Rulings that reinforce contemporary global, regional, and local political trends facilitate ICs in establishing and expanding narrow, intermediate, and extensive legal authority. But global, regional, and national political forces may push in different directions; IC decisions that reinforce one trend may generate opposition elsewhere that undermines the court's authority in fact. The risks of running counter to global, regional, or local trends exist even when ICs apply the law as written, although the risks may be higher when ICs engage in expansionist lawmaking.

\section{Geopolitics and International Politics}

Geopolitical trends and practices produce global frameworks of power and ideas, which in turn influence and enable actions in international institutions

at $8-11$.

81. Ron Levi, John Hagan \& Sara Dezalay, International Courts in Atypical Political Environments: The Interplay of Prosecutorial Strategy, Evidence, and Court Authority in International Criminal Law, 79 LAW \& CONTEMP. PROBS., no. 1, 2016, at 306.

82. Shaffer, Elsig \& Puig, supra note 36, at 261.

83. Vinjamuri, supra note 35 , at 283-86. 
and in regional and national settings. For example, when multilateral organizations such as the World Bank and the International Monetary Fund demand structural economic reforms, or when American and European donors link market access and financial assistance to the adoption of neoliberal economic policies or to the protection of individual liberties, ICs tasked with enforcing free market and human rights rules gain tacit allies. ${ }^{84}$ Even if international institutions and foreign donors do not expressly demand that states comply with IC rulings, the public nature of court decisions means that a government's implementation of those decisions sends a signal about the extent of its commitment to the institution's or donor's goals. As a result, even if powerful external actors do not push states to comply with IC judgments, courts that reinforce the objectives of these actors may more easily generate narrow, intermediate, and extensive legal authority.

Synergy with powerful external actors can be a double-edged sword, however. Support for the post-Cold War objectives of economic liberalism and human rights have soured in much of the developing world. To the extent that ICs enforce rules that reflect externally supported goals that local audiences do not share, it may be difficult for the IC to acquire narrow and intermediate authority. This disjuncture between external and internal goals partly explains, for example, the demise of the Southern African Development Community Tribunal. ${ }^{85}$

\section{Regional Integration Politics}

Regionalism can help to mediate the pathologies created by disjunctures between global and local interests. Regional ICs too, even those modeled on courts in Europe, can sometimes provide a middle ground that both accommodates local laws and policies and diffuses foreign pressure. An example is the IP regime of the Andean Community, a regional integration project among four countries in South America. As is the case for most developing countries, Andean governments have faced significant external pressure to protect the IP rights of foreign businesses. The ATJ acted as a bulwark to uphold a distinctive Andean approach to IP and enabled domestic administrative agencies to push back against national governments that had caved to external pressure for stronger IP protection. The ATJ achieved narrow authority when the agencies complied with its rulings. This case-specific

84. See, e.g., Helfer, Alter \& Guerzovich, supra note 32, at 7-8 (discussing expansion of the ATJ's de jure authority following structural economic reforms in South America).

85. See Laurie Nathan, The Disbanding of the SADC Tribunal: A Cautionary Tale, 35 HUM. RTS. Q. 870, 891 (2013) (contrasting the pro-democracy, pro-human-rights rhetoric adopted to garner favor with foreign donors with the pro-sovereignty preferences of political leaders in Southern Africa). Alter, Helfer, and Gathii further explain how Zimbabwe's President Mugabe drew on his status as the country's liberator and on anti-Western rhetoric to deter other political leaders in the region from opposing his attacks on the SADC Tribunal. See Karen J. Alter, Laurence R. Helfer \& James Thuo Gathii, Backlash Against International Courts in West, East and Southern Africa: Implications for Theories of Judicial Independence, (iCourts Working Paper Series, Paper No. 21; Duke Law Sch. Pub. Law \& Legal Theory Working Paper Grp., Paper No. 2015-19, 2015), http://ssrn.com/abstract=2591837. 
compliance, in turn, laid the groundwork for building intermediate and extensive authority in the specialized field of Andean IP law. ${ }^{86}$

Regional politics are also relevant to ICs operating in the human rights and criminal law issue areas. Moravcsik, for example, attributes the success of the ECtHR to the social and political interests of member states in protecting liberal democracy in the context of the Cold War. ${ }^{87}$ Madsen generally concurs, and observes that changes in regional (geo)politics in the post-Cold War era are creating new challenges-and opportunities-for the ECtHR.

In Africa, many political leaders have attacked the ICC for unfairly targeting international crimes on that continent. Kenyan President Uhuru Kenyatta is a leading champion of this charge, which many see as linked to his own, now-successful efforts to avoid prosecution. ${ }^{88}$ Yet Africa also has highprofile ICC champions, including anti-apartheid activist Desmond Tutu. ${ }^{89}$ As Vinjamuri discusses, the regional battle over prosecutions is making it harder for the ICC prosecutor to garner support for arresting defendants. ${ }^{90}$ Without such support, prosecutions—and narrow authority—remain elusive.

\section{Domestic Politics}

Shifts in domestic politics interact with the geopolitical and regional contexts to influence IC authority. ICs that find fault with the actions of repressive regimes may endure a prolonged absence of narrow authority in the hope that a future government will repudiate the repressive practices of its predecessor. Courts that operate in these transitional circumstances may have little authority in fact for an extended period, but may then see a rapid expansion from narrow, to intermediate, to extensive authority when a new democratic government triggers a virtuous circle of sympathetic officials, impassioned attorneys, and a surfeit of claims focusing on violations attributable to a government no longer in power. ${ }^{91}$ A notable example is the rapid expansion of the IACtHR's authority following the collapse of military regimes in Latin America. ${ }^{92}$ Similarly, Madsen observes that once France and the United Kingdom ended their decolonization struggles, accepting the ECtHR's oversight became politically easier. ${ }^{93}$

86. Helfer, Alter \& Guerzovich, supra note 32, at 3-4.

87. Andrew Moravcsik, The Origins of Human Rights Regimes: Democratic Delegation in Postwar Europe, 54 INT'L ORG. 217, 220 (2000).

88. See African Union accuses ICC of 'hunting' Africans, BBC NEws (May 27, 2013), http://www.bbc.com/news/world-africa-22681894.

89. See Desmond Tutu, In Africa Seeking a License to Kill, N.Y. TIMES (Oct. 10, 2013), http://www .nytimes.com/2013/10/11/opinion/in-africa-seeking-a-license-to-kill.html?_r=0.

90. Vinjamuri, supra note 35 , at 283-86.

91. See generally KATHRYN SIKKINK, THE JUSTICE CASCADE: HOW HuMAN RightS PROSECUTIONS ARE CHANGing WORLD POLITICS (2011) (discussing the global spread of prosecutions for international crimes and violations of human rights, in part in response to IC rulings).

92. See, e.g., COURTNEy Hillebrecht, DOMEstic POlitics AND INTERNATIONAl Human Rights TRIBUNALS: THE PROBLEM OF COMPLIANCE 66-95 (2014).

93. Mikael Rask Madsen, The Protracted Institutionalisation of the Strasbourg Court: From Legal 
At other times, however, domestic legal and social forces may provoke a backlash against ICs. Huneeus discusses Venezuela's opposition to IACtHR judgments against the policies of Venezuelan President Hugo Chávez. ${ }^{94}$ In Russia, President Putin has challenged ECtHR rulings condemning violations of LGBT rights to advance a broader "Eurasia" political strategy that includes appealing to nationalists and conservatives whose oppose such rights.

Political leaders in Africa and the Caribbean have also sought to bolster their domestic political support by enacting draconian criminal penalties for consensual same-sex conduct and LGBT advocacy. ${ }^{96}$ Heated domestic politics create challenges for ICs, such as the challenges to anti-gay laws filed before the CCJ and the EACJ. ${ }^{97}$ International judges who uphold anti-gay laws risk opprobrium from human rights NGOs and American and European governments. But ICs that rule against laws at odds with deeply held local values may see prolonged noncompliance and risk a retrenchment of their authority in fact.

\section{How International Judges Influence Contexts}

This symposium primarily explores how institutional and political factors exogenous to judicial decisionmaking affect IC authority. Yet the judges who serve on ICs often recognize the importance of these factors for establishing, expanding, or defending their court's authority, and they take steps-both inside and outside the courtroom-to influence the contexts in which their court operates.

Several articles in this symposium identify examples of international judges who have attempted to alter or strategically manipulate the contexts in which they operate. Kelemen and Madsen explain how Europe's supranational courts consciously sought to expand their authority during their constitutional founding periods. ${ }^{98}$ Shaffer, Elsig, and Puig discuss how the WTO Appellate Body encouraged the development of an international trade bar by accepting amicus briefs and by allowing private lawyers to participate in WTO proceedings. ${ }^{99}$ Huneeus describes the IACtHR's adoption of "conventionality

Diplomacy to Integrationist Jurisprudence, in THE EUROPEAN COURT OF HUMAN RIGHTS BETWEEN LAW AND POLITICS 43, 51-54 (Jonas Christoffersen \& Mikael R. Madsen eds., 2011).

94. Huneeus, Constitutional Lawyers, supra note 39, at 199-201.

95. Timothy Snyder, Ukraine: The Haze of Propaganda, N.Y. REV. Books BlOG (Mar. 1, 2014, 11:15 AM), http://www.nybooks.com/blogs/nyrblog/2014/mar/01/ukraine-haze-propaganda.

96. Somini Sengupta, Antigay Laws Gain Global Attention; Countering Them Remains Challenge, N.Y. TiMES (Mar. 2, 2014), http://www.nytimes.com/2014/03/02/world/africa/antigay-laws-gain-globalattention-countering-them-remains-challenge.html?_r=0.

97. Caserta \& Madsen, supra note 28, at 113 (discussing challenges to anti-gay immigration laws in Belize and Trinidad); Press Statement, Civil Society Coalition on Human Rights and Constitutional Law, Uganda's Anti-Homosexuality Act Challenged Before the East African Court of Justice (Apr. 25, 2014), http://www.hrapf.org/sites/default/files/publications/14_04_23_cschrcl_press_release_upon_eacj_ reference_filing_final.pdf.

98. Kelemen, supra note 33, at 138; Madsen, supra note 33, at 167.

99. Shaffer, Elsig \& Puig, supra note 36, at 254-55. 
control" to induce national judges to follow Inter-American jurisprudence. ${ }^{100}$ Caserta and Madsen discuss the extrajudicial strategies CCJ judges employed to connect with new audiences and encourage the filing of cases. ${ }^{101}$ Gathii considers how EACJ judges maintained close connections with regional bar associations. ${ }^{102}$ Hagan, Levi, and Dezalay show how prosecutorial strategies for aligning with key constituencies were developed at the Nuremberg Tribunal and the ICTY ${ }^{103}$ And Vinjamuri examines prosecutorial choices that elate one audience while simultaneously raising suspicion among other audiences. ${ }^{104}$

These examples illustrate that international judges can sometimes impact the context in which ICs operate. Yet there are significant limits to what judges can accomplish. No doctrinal innovation can alter the fact that only states can litigate before the WTO Appellate Body. Similarly, IACtHR judges can urge their domestic colleagues to apply Inter-American human rights norms, but some national judges will inevitably resist. ${ }^{105}$ And some contextual factors that impede IC authority are so deeply entrenched that judges can do little about them, as Dickerson explains in stressing the irrelevance of the OHADA Court and OHADA law to the informal economy in Francophone Africa. ${ }^{106}$ That said, international judges who understand the multiple contexts in which ICs operate are likely to be more effective in harnessing support for their respective institutions, as Madsen's discussion of the ECtHR's "legal diplomacy" reveals. ${ }^{107}$

\section{E. The Contextual Factors Investigated in This Symposium}

The contributors to this symposium explore how contextual factors influence the creation, growth, functioning, or diminution of IC authority by making comparisons across contexts. Table 2 provides a snapshot of their findings and related insights. It also serves as a guide for readers interested in looking across the symposium to explore how a particular contextual factor may or may not shape IC authority.

100. Huneeus, Constitutional Lawyers, supra note 39, at 203 (quoting Almonacid Arellano and others v. Chile, 2006 Inter-Am. Ct. H.R. (ser. C) No. 154, para. 124 (Sept. 26, 2006)).

101. Caserta \& Madsen, supra note 28 at 108-14.

102. Gathii, supra note 27 , at 38 .

103. Levi, Hagan \& Dezalay, supra note 81, at 295, 301.

104. See generally Vinjamuri, supra note 35 .

105. Huneeus, Courts Resisting Courts, supra note 19.

106. Dickerson, supra note 35, at 68 .

107. See generally Madsen, supra note 33 . 


\section{Table 2: Contextual Factors Explored in This Symposium}

\begin{tabular}{|c|c|}
\hline Contextual Factors & Comparisons Explored for Different ICs \\
\hline IC design features & $\begin{array}{l}\text { WTO DS—GATT consent-based vs. WTO compulsory jurisdiction } \\
\text { ICC_Self-referral vs. Security Council referral } \\
\text { CCJ_Appellate jurisdiction replacing Privy Council vs. CARICOM original } \\
\text { jurisdiction } \\
\text { International criminal tribunals—Documentary strategy vs. witness-based } \\
\text { strategy } \\
\text { ECtHR_Optional vs. compulsory jurisdiction }\end{array}$ \\
\hline $\begin{array}{l}\text { Alternatives to } \\
\text { litigation }\end{array}$ & $\begin{array}{l}\text { ICJ_Informal dispute settlement by Islamic law states } \\
\text { WTO DS_Dispute settlement under regional and bilateral trade agreements } \\
\text { EACJ_Domestic political and legal alternatives } \\
\text { OHADA_Informal norms } \\
\text { CCJ_Political channels }\end{array}$ \\
\hline $\begin{array}{l}\text { Varying subject } \\
\text { matter }\end{array}$ & $\begin{array}{l}\text { EACJ-Economic disputes vs. human rights disputes } \\
\text { ICJ-Diplomatic immunity vs. territorial disputes } \\
\text { CCJ-Criminal law and human rights vs. economic disputes }\end{array}$ \\
\hline $\begin{array}{l}\text { Varying domestic } \\
\text { audiences }\end{array}$ & $\begin{array}{l}\text { IACtHR_Neoconstitutionalist countries (e.g., Colombia and Chile) vs. } \\
\text { leftist states (e.g., Venezuela) } \\
\text { EACJ_Economic actors vs. human rights NGOs } \\
\text { OHADA—Formal vs. informal economy } \\
\text { ECJ and ECtHR_Old vs. new member states; established democracies vs. } \\
\text { post-communist democracies }\end{array}$ \\
\hline $\begin{array}{l}\text { Varying geopolitical } \\
\text { contexts }\end{array}$ & $\begin{array}{l}\text { ECJ-Cold War vs. post-Cold War setting } \\
\text { CCJ-Privy Council (post-colonial) vs. CARICOM (neoliberal) } \\
\text { WTO DS-Cold War vs. post-Cold War; rise of China } \\
\text { ECtHR_Cold War vs. post-Cold War } \\
\text { International criminal tribunals-Post-WWII occupation vs. post-Cold War } \\
\text { period }\end{array}$ \\
\hline
\end{tabular}




\section{$\mathrm{V}$ \\ THE RELATIONSHIP BETWEEN IC AUTHORITY AND IC POWER}

Our framework analyzes different categories of IC authority by reference to the practices of different audiences. As we have explained, we are chiefly interested in variation and change in these categories across ICs, issue areas, and time. Authority in fact, however, corresponds only roughly to whether an IC is powerful. For example, a court may have de facto authority in some of the disputes that it adjudicates but still not be a politically powerful institution because many legal violations are never brought to court or are the subject of rulings that are ignored.

Powerful ICs, in contrast, have authority in fact that extends across a broad range of issues, states, and types of cases. For any legal issue, a change from narrow to intermediate to extensive authority expands the court's power, defined as the ability to move governments and private actors in the direction indicated by the law. ${ }^{108}$ Yet this observation, and our framework overall, equates ICs that have extensive authority over a broad array of actors and disputessuch as the ECJ and ECtHR in EU and human rights law-with ICs that have extensive authority vis-à-vis only a few actors or technical issues-such as the OHADA Court in some commercial disputes or the ATJ in IP cases.

We view the scalability of our framework as an advantage for the study of ICs, whose authority in fact is often less extensive than their formal delegated authority. We recognize, however, that an IC that has extensive authority is not the same as a court that casts a large shadow over law and politics. To capture variation in IC power, we introduce a third dimension: the extent to which a court has narrow, intermediate, or extensive authority over a broad subject matter jurisdiction and many state parties.

Figure 2 captures this third dimension by adding height to the circles of IC authority displayed in figure 1 above. The white cone corresponds to the white circles of figure 1, representing the IC's formally delegated jurisdiction. The greater the height of the white cone, the broader its base and the more expansive the court's formally delegated authority. For an IC with no de facto authority, the white cone would remain a blank space. ICs with some authority in fact would be represented by a shaded cone nested inside the white cone.

Figure 2 offers the key insight that the size of the shaded cone varies along two dimensions - width and height — each of which can change independently of the other. The width of the shaded cone indicates whether an IC has narrow, intermediate, or extensive authority for a specific set of legal issues, such as diplomatic immunity disputes or cases involving state violence. A larger shaded cone suggests that more audiences recognize an IC's authority for a specific set of issues and cases. To make the diagram more readable, the cone uses uniform shading to reflect extensive IC authority. The cone replicates figure 1 at the top

108. Laurence R. Helfer, The Effectiveness of International Adjudicators, in OXFORD HANDBOOK, supra note 2 , at 464,466 . 
of the large shaded cone, to demonstrate that figure 1 is a slice of the cone.

The height of the shaded cone shows the expansiveness of the jurisdiction that an IC actually exercises. The taller the shaded cone, the more powerful the IC. Because ICs seldom exercise the entire jurisdiction that states formally delegate to them, the shaded cone is depicted as smaller than the white cone. However, an IC might use judicial lawmaking to expand its own jurisdiction to the point that the shaded cone grows taller than the white cone.

To illustrate variations of IC power, figure 2 includes three differently sized shaded cones that show three different ICs, each of which has extensive authority. The expansiveness of each court's jurisdiction varies, with the result that each court's influence also varies.

The small cone "A" at the bottom of the diagram depicts an IC with extensive authority over the entire zone of its delegated jurisdiction. Yet because that jurisdiction is limited, the court has minimal power. An example is the Arab Investment Court, an IC whose jurisdiction is limited to reviewing nonimplementation of arbitral awards in disputes between Arab League states and firms. Even if the court develops narrow, intermediate, and extensive authority across its entire subject matter competence and all actors who have or might litigate disputes, it would still have very limited political influence. ${ }^{109}$

109. See generally Walid Ben Hamida, The First Arab Investment Court Decision, 7 J. WORLD INVEST. \& TRADE 699 (2006) (discussing the Arab Investment Court). 
Figure 2: The Relationship of IC Authority to IC Power

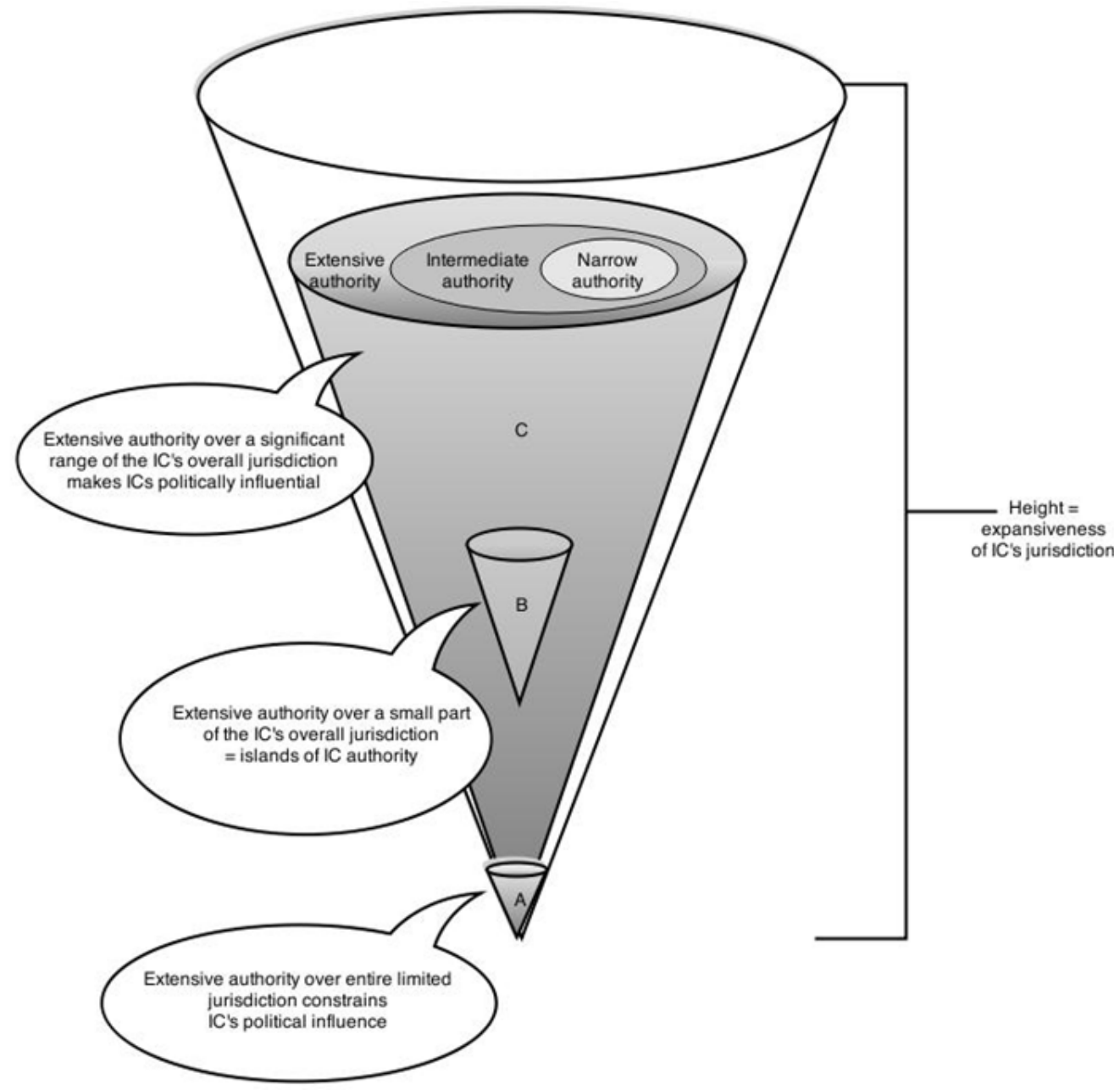

An IC can also be minimally powerful if its extensive authority is confined to a small fraction of a broader delegated jurisdiction. Cone "B" in the middle of figure 2 shows an IC with narrow, intermediate and extensive authority limited to an island within a wider subject matter jurisdiction. A good example of this is the ATJ in IP cases. Another type of island exists, as Huneeus' discussion of the Inter-American system reveals, when only some of the countries that have signed on to an IC's jurisdiction recognize its intermediate and extensive authority.

In contrast, the larger shaded cone "C" represents an IC that has extensive authority extending over a wide-ranging subject matter and that encompasses all or most of its member states. The combination of extensive authority and expansive jurisdiction makes such a court both politically influential and effective. The ECJ and the ECtHR are examples of such courts.

We drew these cones as monoliths. But our theory of authority allows for an 
IC to have extensive authority over some issues, audiences, and countries and no authority over others that fall within the court's formal authority. In reality, IC authority may thus resemble Swiss cheese. Vinjamuri's contribution to this symposium, for example, identifies the absence of IC narrow authority for certain types of cases and audiences. ${ }^{110}$ The larger and more numerous the holes, the less the overall volume of IC authority and power.

The third dimension of IC authority in figure 2 suggests that for an IC to become politically powerful it must: (1) have a formal or self-created jurisdiction that extends over multiple politically consequential issue areas, (2) exercise de facto authority that extends across the breadth of this jurisdiction, (3) extend this authority to at least intermediate and preferably also extensive authority, and (4) have few gaps in de facto authority. This topic merits further study.

\section{VI}

\section{CONCLUSION: THE AUTHORITY OF ICS IN A COMPLEX WORLD}

This introduction has provided a comprehensive framework for analyzing and empirically assessing the de facto authority of ICs. The judicial nature of ICs makes them a distinct type of international institution. The formal power that states delegate to ICs establishes, as a legal matter, their right to rule. Yet because ICs operate in a context of regime complexity, in which there are competing and overlapping decisionmakers that lack an accepted hierarchy, turning that formal mandate into de facto authority raises political, legal, and practical challenges.

We developed metrics to evaluate empirically whether ICs have narrow, intermediate, or extensive legal authority. According to our definition, ICs have authority when the litigants (narrow authority), the court's compliance partners (intermediate authority), and the legal field (extensive authority) recognize the binding nature of IC rulings and undertake meaningful steps to give effect to those rulings. The symposium's contributors apply these metrics to ten different ICs spanning economic, human rights, and mass atrocities issue areas, exploring how contextual factors shape an IC's de facto authority. Important contextual factors include the availability of litigation alternatives, the discretionary decisions of prosecutors, the openness of domestic lawyers and judges to IC litigation, the compatibility of international and domestic laws and legal practices, and the geopolitics of the time. Some of these factors can be influenced by international judges, but many cannot.

Finally, we examined the relationship between IC authority and IC power. Although authority is a form of power and the means through which ICs become powerful institutional actors, our investigation of varied IC authority demonstrates that the two concepts are in fact distinct. We conceive of a politically powerful IC as one that has attained narrow, intermediate, and

110. See generally Vinjamuri, supra note 35 . 
extensive authority that encompasses a wide range of politically salient topics across its membership. Some of the ICs in this symposium have attained this level of influence. Others have narrow, intermediate, or even extensive authority, yet they nonetheless remain marginal political actors for some legal issues, or in some member states, or both. The contributors show, however, that even where an IC's authority is circumscribed, it sometimes exerts influence over specific issue areas.

A key theoretical benefit of our framework and this symposium is the conception of IC authority as varying by audience. This recognition surmounts a number of artificial binaries that commentators impose when they focus on only one IC or on only one audience.

First, we challenge the binary claim that ICs either do or do not have authority. The contributors to this issue provide many examples of audiences and interlocutors differing in their embrace of IC rulings. This means that the support of the litigating parties-which may include a single lawyer, activist NGO, or sympathetic government—although necessary and sufficient to confer narrow authority in the case at hand-is not sufficient for an IC to gain intermediate or extensive authority. Conversely, opposition to an IC ruling by a single actor does not in itself signify that a court lacks any authority in fact.

A second erroneous binary is the idea that legal authority resides either at the international or at the national level. By design, ICs exercise their legal authority in tandem with domestic actors, whether in a complementary or a contested fashion. Domestic actors who recognize an obligation to comply with IC rulings and engage in meaningful practices toward that end affirm IC authority without necessarily diminishing their own authority.

Our separation of authority and legitimacy renders a third binary unsustainable. In particular, we contest the claim that an IC is either authoritative and legitimate on the one hand, or illegitimate and thus unauthoritative on the other. Longstanding debates about the compatibility of democracy, parliamentary sovereignty, and international judicial review have gained traction precisely because neither de jure nor de facto legal authority is the same as legitimacy.

Finally, our framework suggests a strategy through which ICs can become politically influential institutions. International judges and their supporters should look beyond narrow authority and look outside the courtroom to build support among future compliance partners and the larger legal field. This further implies that it is not enough for international judges to focus on delivering high-quality legal rulings. Nor should international judges be satisfied once a legal ruling garners compliance. Building and maintaining IC authority remains a collective and fragile enterprise, one that is shaped by a range of contextual factors and requires the ongoing care and attention of a wide range of actors. 